\title{
Institutional Design of State Aid Authorities in South East Europe: The Unfit Legal Transplant and Its Ramifications
}

\author{
Dušan V. Popović
}

\section{Introduction}

All countries in South East Europe (hereinafter, SEE) ${ }^{1}$ aspire to join the European Union. This political aim has been confirmed and strengthened by these countries participating in the Stabilization and Association Process, established by the EU. The Process, launched in 1999 and re-affirmed at the Thessaloniki European Council meeting in 2003, sets out common political and economic goals to be achieved by the participating countries. The Process rests on the Stabilization and Association Agreements (hereinafter, SAA), signed by the European Union with each of the participating countries, and the EU's financial assistance, aimed at strengthening the rule of law, institutional development of a market economy, and structural adjustment. The SEE countries have reached different stages in the European integration process. Albania signed the SAA in 2006 and was granted EU candidate status in 2014. Bosnia-Herzegovina signed the SAA in 2008 and submitted its application to join the EU in 2016. The FYR Macedonia signed the SAA in 2001 and was granted EU candidate status in 2005. Kosovo* ${ }^{2}$ signed the SAA in 2014 and the EU has been facilitating the high-level dialogue between

\footnotetext{
${ }^{1}$ The term South East Europe shall be used to designate Balkan countries that are candidates or potential candidates for membership of the European Union.

${ }^{2}$ The asterisk refers to the following footnote: "This designation is without prejudice to positions on status, and is in line with UNSC 1244 and the ICJ Opinion on the Kosovo Declaration of Independence."

D. V. Popović

Faculty of Law, University of Belgrade, Belgrade, Serbia

e-mail: dusan.popovic@ius.bg.ac.rs
} 
Kosovo* and Serbia since 2012. ${ }^{3}$ Montenegro signed the SAA in 2007 and was granted EU candidate status in 2010. Serbia signed the SAA in 2008 and was granted EU candidate status in 2012.

As an important prerequisite for accession to the European Union, the SEE countries are required to introduce a national system of state aid control. The obligation to introduce state aid monitoring systems stems from the Stabilization and Association Agreements, but also from the Central European Free Trade Agreement and the Energy Community Treaty; the latter two initiatives may be observed as part of the wider European integration process. The national state aid control systems are envisaged as transitional mechanisms, since the monitoring of state aid will be carried out by the European Commission once the SEE countries accede to the Union. As demonstrated by the experience of countries in Central and Eastern Europe, effective enforcement of the national state aid rules is one of the essential requirements concluding the negotiations on the competition policy chapter.

This paper analyses the reasons for the introduction of state aid control in SEE countries (Sect. 2) and the types of institutional design of these authorities (Sect. 3). It concludes by considering the reasons for the observed inefficiency of state aid monitoring authorities in the region of South East Europe (Sect. 4).

\section{Duty to Introduce State Aid Control}

The Stabilization and Association Process draws on the experience of pre-accession agreements of Central and East European countries (hereinafter, the CEEC). The association agreements ${ }^{4}$ concluded with CEECs required that each of these countries establish a temporary monitoring authority in charge of state aid control pending the country's accession to the European Union. ${ }^{5}$ Once the country accedes to the Union, the competence is transferred to the European Commission. In the same manner, the Stabilization and Association Agreements concluded with the SEE countries set a general obligation for candidate or potential candidate countries to adopt national state aid legislation and establish a state authority competent for the enforcement of the said rules. The SEE countries need to ensure that their legislation is aligned with

\footnotetext{
${ }^{3}$ Kosovo* declared independence from Serbia in 2008. Although its independence is not recognized by all EU Member States, Kosovo* participates in the Stabilization and Association Process separately from Serbia.

${ }^{4}$ The association agreements concluded between the EC and its Member States, and the Central and Eastern European countries that joined the EU in 2004/2007 were usually referred to as the "Europe agreements".

${ }^{5}$ See: the Europe Agreement establishing an association between the European Communities and their Member States, of the one part, and the Republic of Poland, of the other part, Art. 63 (4) (b) and (7), and Art. 68. Under these articles, Poland had to ensure transparency in the area of public aid and to approximate the country's existing and future legislation with that of the EC.
} 
the EU acquis and properly enforced by the competent authority. Regarding state aid, each of the Stabilization and Association Agreements concluded with the SEE countries provides that any "(...) state aid which distorts or threatens to distort competition by favouring certain undertakings or certain products, as they may affect trade between the Community and [associated country], shall be incompatible with the proper functioning of the Stabilisation and Association Agreement". 6 This definition is modelled upon the definition of incompatible state aid laid down by Art. 107, para 1 TFEU. The agreements concluded with SEE countries also provide that suspected practices shall be assessed on the basis of criteria arising from the application of the competition rules applicable in the Community, in particular from Art. 107 TFEU and interpretative instruments adopted by the Community institutions. ${ }^{7}$ Therefore, the associate countries have to assess the state aid schemes on the basis of criteria arising from the application of secondary legislation, frameworks, guidelines and other relevant administrative acts that are in force in the EU, and those that will be adopted following the entry into force of the SAA, as well as on the basis of the criteria developed in the case law of the EU courts, and from any decision taken by the Association Council. The advancement of each country participating in the Stabilization and Association Process is assessed in annual Progress Reports, published by the European Commission.

Following the conclusion of the SAA, the countries in South East Europe adopted comprehensive legislative frameworks for state aid control, which are generally harmonised with EU law. ${ }^{8}$ A detailed analysis of the national state aid rules reveals that further approximation with EU law is needed with respect to secondary legislation (Popović and Caka 2017; Botta 2013). For example, in most SEE countries the notion of de minimis aid or aid for restructuration is not conceive in line with the General Block Exemption Regulation ${ }^{9}$ and the de minimis Regulation. ${ }^{10}$ Simultaneously with the adoption of the first national state aid acts, the SEE countries established their state aid monitoring authorities, in line with the requirements of the

\footnotetext{
${ }^{6}$ See: SAA with Albania, Art.71 (1) (iii); SAA with Bosnia-Herzegovina, Article 71 (1); SAA with the FYR Macedonia, Art. 69 (1) (iii); SAA with Kosovo*, Art. 75 (1); SAA with Montenegro, Ar.73 (1) (iii); SAA with Serbia, Art.73 (1) (iii).

${ }^{7}$ See: SAA with Serbia, Art.73 (2).

${ }^{8}$ Since the Kosovo* proclamation of independence was not recognized by five EU Member States and Serbia, the EU signed the SAA with Kosovo* only in 2014, when the EU-sponsored negotiations between Belgrade and Pristina made progress. Kosovo* adopted its national state aid legislation and established the monitoring authority in 2011, several years before the entry into force of the SAA. Therefore, the establishment of the state aid authority was not the result of compliance with the SAA but a reaction to criticism expressed in the European Commission Progress Reports for 2008, 2009, and 2010.

${ }^{9}$ Commission Regulation (EU) No. 651/2014 declaring certain categories of aid compatible with the internal market in application of Articles 107 and 108 of the Treaty (hereinafter, GBER), Official Journal of the European Union n ${ }^{\circ}$ L187/1, 26.6.2014.

${ }^{10}$ Commission Regulation (EU) No. 1407/2013 on the application of Articles 107 and 108 of the Treaty on the Functioning of the European Union to de minimis aid (hereinafter, De minimis Regulation), Official Journal of the European Union n ${ }^{\circ}$ L352/1, 24.12.2013.
} 
Stabilization and Association Agreements. All SAAs in (almost) identical manner prescribe the duty to establish such monitoring authorities: "[The associated country] shall establish an operationally independent authority which is entrusted with the powers necessary for the full application of [the state aid rules] within one year from the date of entry into force of this Agreement. This authority shall have, inter alia, the powers to authorise state aid schemes and individual aid grants (...) as well as the powers to order the recovery of state aid that has been unlawfully granted." 11 The SAAs do not further specify requirement for operational independence of the national state aid authorities. Logically, this requirement should be understood as excluding any instruction or interference by other state bodies in the activities of the state aid authority.

The "neutral" position of the European Union towards the choice of the appropriate institutional design of the national state aid authority in SEE countries does not come as a surprise since it is in line with the earlier EU approach in other areas of competition law enforcement. For example, when the European Union introduced decentralised competition law enforcement, the European Commission merely prescribed that the national competition authorities (hereinafter, NCA), henceforth competent to enforce Arts. 101 and 102 TFEU, should be designated in such a way that they effectively comply with the provisions of Regulation $1 / 2003 .{ }^{12}$ The choice of the institutional design of NCAs was therefore left entirely to the discretion of the Member States, which is in line with the principle of institutional and procedural autonomy of the EU Member States. As a result, NCAs take different forms in different Member States, ranging from administrative bodies to judicial authorities. Furthermore, in a number of Member States a specific form of government intervention exists in merger cases. It usually entails that the government may intervene on grounds of public interest after the NCA has analysed the impact of the merger on consumers and businesses. ${ }^{13}$

In addition to adopting national state aid rules and establishing the monitoring authority, the duty to introduce state aid control includes the task of establishing an inventory of state aid schemes and drafting a state aid regional map for each SEE country. Under the SAA, within 4 years from its entry into force, the state aid authority should complete a comprehensive inventory of the aid schemes existing in the country. The establishing of the inventory is the first activity that the authority

\footnotetext{
${ }^{11}$ See: SAA with Montenegro, Art. 73 (4).

${ }^{12}$ Council Regulation (EC) No 1/2003 of 16 December 2002, on the implementation of the rules on competition, laid down in Articles 81 and 82 of the Treaty, Official Journal of the European Community $\mathrm{n}^{\circ} \mathrm{L} 1 / 1,4.1 .2003$, Art. 35. Regulation 1/2003 revolutionised the enforcement of EU competition law by abandoning the notification system and decentralising enforcement of Arts. 101 and 102 TFEU (ex Arts.81 and 82 TCEU).

${ }^{13}$ Commission Staff Working Document SWD (2014) 231/2, Enhancing Competition Enforcement by the Member States' Competition Authorities: Institutional and Procedural Issues, accompanying the document Communication from the Commission to the European Parliament and the Council Ten Years of Antitrust Enforcement under Regulation 1/2003: Achievements and Future Perspectives, COM (2014) 453.
} 
should carry out. By the end of the transition period ( 4 or 5 years, depending on the country), the state aid authority is required to draft a state aid regional map for the country, indicating the maximum aid intensity per region of the country, on the basis of the data concerning the GDP per capita in each region. The regional aid map is then assessed by the European Commission.

As it has already been underlined, the duty of SEE countries to establish a national state aid legal framework does not stem only from their participation in the Stabilization and Association Process, but also from the Central European Free Trade Agreement (hereinafter, CEFTA), to which these countries are parties. The original CEFTA agreement was concluded in 1992 by the members of Visegrad Group: Poland, Czech and Slovak Federative Republic and Hungary. CEFTA was conceived as a free trade agreement, the purpose of which was to facilitate the transition of former communist Central European countries to market economies of a West European style. The membership in CEFTA is supposed to be of a temporary character: once the participating country joins the European Union, its CEFTA membership ends. The original agreement was amended several times in order to allow other Central and East European countries to join. Slovenia joined CEFTA in 1996, Romania in 1997, Bulgaria in 1999, Croatia in 2003 and the FYR Macedonia in 2006. Following the 2004 enlargement of the EU, the CEFTA membership ended for most of the participating countries. Therefore, the new "enlarged" CEFTA agreement $^{14}$ was signed in 2006, to which Albania, Kosovo*, Moldova, Montenegro, Serbia and Bosnia-Herzegovina adhered.

Article 21 CEFTA lays down a general prohibition on state aid: "Any aid granted by a Party or through State resources in any form whatsoever which distorts or threatens to distort competition by favouring certain goods shall, in so far as it may affect trade between the Party concerned and other Parties to this Agreement, be incompatible with the proper functioning of this Agreement." CEFTA also requires the Parties to the Agreement to assess state aid schemes under the conditions laid down by Art. 107 TFEU. The Parties are required to ensure transparency in the area of state aid, inter alia by reporting to the CEFTA Joint Committee on the total amount and the distribution of the aid and by providing to other Parties information on aid schemes. Although there is a direct reference to Art. 107 TFEU in the Agreement, CEFTA state aid framework differs significantly from the one provided under SAAs. CEFTA Member States are not explicitly required to establish a national state aid control authority. Instead, CEFTA provides for a system of mutual withdrawal of the trade concessions, inspired by the WTO Dispute Settlement Understanding. ${ }^{15}$ This system is initiated only if a Party to the Agreement decides

\footnotetext{
${ }^{14}$ Agreement on Amendment of and Accession to the Central European Free Trade Agreement, also referred to as CEFTA 2006.

${ }^{15}$ The dispute settlement procedure is laid down in Art. 24 CEFTA. The Parties should first attempt to resolve any differences between them through direct consultations. Nevertheless, a party may decide to refer the case to the Joint Committee. The Joint Committee examines the case without delay and may make any recommendation needed to put an end to the difficulties notified. In the absence of such recommendation and if the problem persists, the complaining Party may adopt
} 
to challenge another Party that allegedly does not comply with the duty to prohibit state aid (Dangerfield 2006). The complaining Party may also take countervailing measures in accordance with the relevant Articles of GATT and the WTO Agreement on Subsidies and Countervailing Measures or related internal legislation.

Finally, the requirement to introduce a state aid control stems from membership of the SEE countries in the Energy Community, an international organization dealing with energy policy. This international organization was established by the European Union, and it brings together the EU, the SEE countries (Albania, Bosnia-Herzegovina, Kosovo*, the FYR Macedonia, Montenegro, and Serbia), and countries from the Black Sea region (Moldova, Ukraine). ${ }^{16}$ One of the aims of this organization, established by an international treaty in 2005 , is to enhance competition at the regional level and to exploit economies of scale. ${ }^{17}$ Under Article 18 of the Energy Community Treaty (hereinafter, EnCT), any public aid which distorts or threatens to distort competition by favouring certain undertakings or certain energy resources shall be incompatible with the proper functioning of the Treaty. Any such practices should be assessed on the basis of criteria arising from the application of the rules of Article 107 TFEU.

Similarly to CEFTA, EnCT does not explicitly require from Contracting Parties to establish a state aid monitoring authority. However, a Party which does not comply with EnCT requirements (e.g. by favouring its national energy producers and distributors), may face sanctions. Under the Rules on dispute settlement, the Energy Community Secretariat may start an investigation if one of the Contracting Parties does not properly implement the EnCT. The Secretariat may bring the case to the Ministerial Council, which can withdraw the voting rights of the Contracting Party. The EnCT Rules on dispute settlement were amended in 2015 to introduce a fast-track procedure, allowing the Secretariat to directly submit a reasoned request to the Ministerial Council without preliminary procedure (i.e. without first issuing a reasoned opinion). The EnCT Rules on dispute settlement were enforced in several state aid related cases. For example, in July 2016 the Secretariat sent an opening letter to the Republic of Serbia for its failure to comply with the Energy Community

appropriate measures necessary in order to remedy the situation. At present, any dispute between CEFTA members arising out of competition issues and any dispute in which only one of the parties is also a WTO member must be resolved by the CEFTA internal dispute resolution mechanism (Biukovic 2008).

${ }^{16}$ Georgia, Armenia, Norway and Turkey participate as observers. Georgia is presently in the process of joining the Energy Community as a full-fledged member. The ministers took the decision on Georgia's accession in October 2016. As of January 2017, Georgia is in the process of completing its internal procedures for approval of the accession to the Energy Community.

${ }^{17}$ Up until 1992, there was lack of clear competence of the European Community to take measures on energy matters. It was only the Treaty of European Union (Art. 3 (1) u) that empowered the EU to take measures in the sphere of energy. Prior to the adoption of the said Treaty, the measures in the sphere of energy were taken on the legal basis of other EC competences, such as the internal market or competition policy (Karova 2010: 2). At present, the EU is not only competent to take internal measures on energy issues, but may also influence the energy policy of the candidate and potential candidate countries via the Energy Community. 
state aid acquis. The Republic of Serbia failed to comply with its obligations under the EnCT, in particular Articles 18 and 19 thereof, because the national state aid authority either did not assess or incorrectly assessed the compatibility of state aid granted to Elektroprivreda Srbije (public enterprise Electric Power Industry of Serbia) for the Kolubara B power plant project. ${ }^{18}$ In September 2010, the Secretariat sent an Opening Letter to Bosnia-Herzegovina, expressing the preliminary view that this country had failed to fulfil its obligations under the EnCT, by not adopting legislation prohibiting state aid and enforcing that prohibition. ${ }^{19}$ Following the opening of a dispute settlement procedure, in 2012 Bosnia-Herzegovina adopted an act on state aid control and established the monitoring authority.

\section{Types of State Aid Authorities in SEE Countries}

The analysis of the institutional design of state aid monitoring authorities has revealed that SEE countries largely chose to establish an authority with close links to the government. In Albania, Bosnia-Herzegovina, Kosovo*, Montenegro and Serbia, the state aid authority takes the form of a unit either within the ministry of finance or the ministry of economy, or of a collegial body formed by representatives of different ministries, but formally separated from the Government. Only the FYR Macedonia has chosen to design its state aid authority in a different manner, by entrusting the existing competition authority with the task of state aid control. The first type of a state aid authority was actually "transplanted" from countries in Central and Eastern Europe. Similar authorities existed in the majority of CEECs in the pre-accession period (e.g. in Estonia, Slovenia, Estonia, Hungary, and the Czech Republic). The second model of a single competition and state aid authority also existed in certain CEECs. In Poland, for example, the president of the NCA was in charge of authorising state aid (Piszcz 2011:42).

\subsection{Authority Closely Linked to the Government}

The Albanian Law on State Aid $^{20}$ provides for the establishment of the State Aid Commission and the State Aid Directorate, as bodies put in charge of controlling the granting of state aid. The State Aid Commission is responsible for authorising state aid, under the proposals of the State Aid Directorate. ${ }^{21}$ The Commission is the main

\footnotetext{
${ }^{18}$ Case ECS 11/14: RS/State aid.

${ }^{19}$ Case ECS 01/10: BH/Competition.

${ }^{20}$ Albania, Law 9374 On State Aid, 21 April 2005, Official Gazette No 36, 1311.

${ }^{21}$ Albania, Government Decision n ${ }^{\circ}$ 182, 21 March 2006, Official Gazette No 0, 30.
} 
decision-making body responsible for the control of state aid. ${ }^{22}$ The Commission's proclaimed independence from the Government may be called into question given the composition of this body and the rules on the appointment of its members. The Commission is chaired by the minister of economy, who is member of the Commission ex officio. Three other members of the Commission are appointed by the government, nominated by the minister of finance, the minister of European integration, and the minister of justice, in view of their "proficiency and experience in the area of economy". One member is nominated by civil society. ${ }^{23}$ The State Aid Commission reports annually to the government. ${ }^{24}$ On the other hand, the State Aid Directorate $^{25}$ represents a special department within the Ministry of Economy, which provides the State Aid Commission with all the necessary input for its decision-making process. It identifies and analyses the legal and economic aspects of state aid schemes and individual aid, prepares investigative reports, and drafts the guidelines, which are subsequently approved by the State Aid Commission. Given the fact that the members of the State Aid Directorate are employees of the Ministry of Economy, there is undoubtedly a substantial conflict of interests each time the Directorate assesses the state aid granted by that ministry.

In Bosnia-Herzegovina, the authority charged with state aid control is the State Aid Council. The members of the State Aid Council are appointed by the Council of Ministers of Bosnia-Herzegovina and the governments of the country's three units (Republic of Srpska, Federation of Bosnia-Herzegovina, District of Brčko). The Council members are appointed from among "renowned economic or legal experts" and must not exercise any duty that may expose them to conflict of interest. ${ }^{26}$ Each of the three constituent peoples of Bosnia-Herzegovina must be represented by at least two members in the Council. The constituency of peoples as a collective political right of ethnic communities in Bosnia-Herzegovina (Serbs, Croats, and Bosniaks) was provided as a constitutional category by the Washington and Dayton peace agreements which put an end to the war, in 1995. However, such rule precludes $\mathrm{BH}$ citizens who do not belong to any of the constituent peoples from running for a particular government office (Begić and Delić 2013). The independence of the State Aid Council is under threat from not only the manner in which its members are appointed, but also the irregular and insufficient financing of its activities. $^{27}$

\footnotetext{
${ }^{22}$ Albania, Law on State Aid, as amended by Act No 21/2016, 10 March 2016, Official Gazette No 47, 3140, Art. 16 (2).

${ }^{23}$ Albania, Law on State Aid, Art. 16 (2).

${ }^{24}$ Ibid, Art. 16 (3-4).

${ }^{25}$ Ibid, Art. 18.

${ }^{26}$ Bosnia-Herzegovina, Law on the System of State Aid, Official Gazette of Bosnia-Herzegovina No 10/12, Art. 7.

${ }^{27}$ The European Commission warned in several Progress Reports that the Secretariat of the BH state aid authority was not yet fully operational. See Bosnia-Herzegovina 2015 Progress Report, SWD (2015) 214 final, 41-42.
} 
In Kosovo*, the competence for monitoring the state aid is split between the State Aid Commission and the State Aid Office. The system of state aid control in Kosovo* is thus very similar to the Albanian system. The State Aid Commission consists of the minister of finance, the minister of European integration, the minister of trade and industry, the chair of the Association of the Municipalities of Kosovo, and one representative from civil society. ${ }^{28}$ The members of the Commission are appointed by the Government of Kosovo, nominated by the minister of finance, for a period of 4 years. The Commission shares its competence in the area of state aid with the State Aid Office, an administrative unit within the Kosovo Competition Authority. The Office is responsible for receiving and analysing notifications and other data concerning aid schemes and individual aid. The Office prepares assessment reports and decisions for the State Aid Commission. The Office reports to the Kosovo Competition Authority. The Office is not yet fully operational (Ceku 2015: 121-122), which has regularly been criticised by the European Commission in its Progress Reports. In the most recent Report, the Commission concludes that the activities of the State Aid Office have so far been limited to distributing notification forms to potential aid granters and that the Office does not have the capacity to screen existing aid schemes, as required by the SAA. No decisions on state aid have been issued in the past 3 years. ${ }^{29}$

In Montenegro, the members of the Commission for the Control of State Aid are appointed by the Government, following nomination by the Ministry of Economy, the Ministry of Sustainable Development and Tourism, the Ministry of Transport and Maritime Affairs, and the Association of Employers. The candidate for the president of the Commission is proposed by the Ministry of Finance. This creates potential for conflict of interest, given the fact that the majority of aid schemes and individual aid are granted by the ministries represented in the Commission. This has also been noted by the European Commission in its 2015 Montenegro Progress Report. ${ }^{30}$ Furthermore, the members of the Montenegrin state aid authority need not necessarily be specialists in the area of competition law. The Law on State Aid Control only prescribes that the member of the Commission "must have a bachelor degree in economics or law". ${ }^{31}$ The lack of expertise in competition law and/or state aid control may make the members of the state aid authority easily influenced by the Government and businesses. The current enforcement record of the Commission for State Aid Control does not demonstrate that the body has the necessary credibility, powers and resources for the full application of state aid rules. ${ }^{32}$

In Serbia, the Commission for State Aid Control was established under the auspices of the Ministry of Finance. The members of the Commission for State

\footnotetext{
${ }^{28}$ Kosovo, Law on State Aid, No 04/ L-024, Official Gazette 13/2011.

${ }^{29}$ See Kosovo 2016 Progress Report, SWD (2016) 363 final, 47-48.

${ }^{30}$ See Montenegro 2015 Progress Report, SWD (2015) 210 final, 36.

${ }^{31}$ Montenegro, Act on State Aid Control of, Official Gazette of the Republic of Montenegro No 74/09 and 57/11, Art. 11.

${ }^{32}$ See Montenegro 2015 Progress Report, SWD (2015) 210 final, 36.
} 
Aid Control are appointed by the government from among persons who possess "expert knowledge in the field of state aid, competition, and/or EU legislation", 33 nominated by the ministries of finance, economy, infrastructure and environmental protection, as well as the Commission for the Protection of Competition. The member nominated by the Ministry of Finance is the chairperson of the Commission for State Aid Control, while the representative of the Commission for the Protection of Competition serves as a deputy chairperson. The Law on State Aid Control attempts to resolve potential conflict of interest by prescribing that a member of the Commission who is at the same time the representative of the aid grantor may not take part in the decision-making process, although he/she may provide additional information within the state aid control procedure. ${ }^{34}$ The European Commission has on several occasions criticised the potential for conflict of interest within the Serbian state aid authority. For example, in its 2015 Progress Report, the European Commission emphasised that the operational independence of the Commission for State Aid Control still remains to be demonstrated. ${ }^{35}$ The similar finding has been repeated in the latest Progress Report: "The Republic of Serbia has to take steps to make the Commission for State Aid Control more independent and effective." ${ }^{36}$ Further to the issue of composition of the Commission for State Aid Control, its ambiguous legal status may also generate its increased dependency on the executive branch. The Law on State Aid Control does not define the legal status of the Commission, aside from stating that the latter shall be "operationally independent in performing its duties". 37 Consequently, the Commission cannot be classified as the Government's working group, an independent agency, or an administrative organization within the meaning of the Law on General Administrative Procedure. The proclaimed operational independence of the Commission is additionally compromised by its financial dependency on the Ministry of Finance, since the Commission does not have a separate budget.

\subsection{Independent Authority Accountable to Parliament}

As our analysis has demonstrated, the large majority of SEE countries (Albania, Bosnia-Herzegovina, Kosovo*, Montenegro, Serbia) have decided to entrust the competence of enforcing competition and state aid rules to two different authorities. While the competition law enforcement is entrusted to an administrative agency

\footnotetext{
${ }^{33}$ Serbia, Act on State Aid Control, Official Gazette of the Republic of Serbia No 51/2009, Art. 6 (4).

${ }^{34}$ Ibid, Art. 21 (2).

${ }^{35}$ See Serbia 2015 Progress Report, SWD (2015) 211 final, 36.

${ }^{36}$ See Serbia 2016 Progress Report, SWD (2016) 361 final, 38.

${ }^{37}$ Serbia, Law on State Aid Control, Art. 6 (7).
} 
accountable to parliament, ${ }^{38}$ the enforcement of state aid rules has been assigned to an administrative body of doubtful independence from the executive power. Further to the jurisdictions we already analysed, the latter model of a state aid authority closely linked to the government was followed by the FYR Macedonia until 2006. In this country, the state aid control was first exercised by a separate authority-the Commission for State Aid Control, established under the 2003 Law on State Aid. ${ }^{39}$ The members of the Commission were appointed by the government and administrative support for its activities was provided by the Ministry of Economy. Following the 2006 amendments to the Law on State Aid, the competence for state aid control was transferred to the existing Commission for the Protection of Competition. The Commission, which was already in charge of enforcement of other competition rules (prohibition of anti-competitive agreements and abuse of a dominant position, control of concentrations) was established as an independent state agency, with full operational autonomy. Its members are appointed by parliament.

The institutional design of a state aid authority that the FYR Macedonia opted for in 2006 is certainly preferable to the one chosen by other countries in South East Europe, for at least two reasons. First, there are very few experts in the area of competition law and state aid in the SEE countries, especially among civil servants, so their concentration into a single authority would be beneficial to the quality of market analysis. Second, a single "enlarged" authority is not only formally protected from the government's direct influence, but it would also be better prepared to deal with the tactics of informal influence employed by both the executive power and businesses. Unfortunately, both the Government and the Parliament of the FYR Macedonia failed to provide adequate conditions for the smooth performance of the "enlarged" authority, which remains understaffed and under budgeted. As noted by the European Commission, the administrative capacity of the state aid division within the Macedonian Commission for the Protection of Competition is inadequate, as it lacks staff and equipment. It only has three staff members to deal with a growing number of cases and outdated equipment. ${ }^{40}$ The Macedonian experience of merging the state aid authority with the NCA reminds us that, regardless of the clear benefits of having a single authority, there is also a danger of neglecting one of its functions. In such multiple function authority it is of the outmost importance to provide adequate conditions for the proper exercising of each of the authority's competences.

\footnotetext{
${ }^{38}$ As a rule, the members of a collegial decision-making body are appointed by parliament from among experts in competition law and policy. The national competition authority is accountable to parliament, to which it reports annually.

${ }^{39}$ The FYR Macedonia, Law on State Aid, Official Gazette 24/2003.

${ }^{40}$ See The FYR Macedonia 2016 Progress Report, SWD (2016) 715 final, 39-40.
} 


\section{Concluding Remarks: The Reasons for Inefficiency}

All countries in South East Europe met the basic requirements under the Stabilization and Association Agreement, CEFTA, and the Energy Community Treaty in the area of state aid - they adopted national state aid rules and established a state aid monitoring authority. However, the enforcement record of these authorities is unsatisfactory. Analysis of the annual reports of state aid authorities in SEE countries reveals that they tend to adopt only decisions approving the notified state aid. There are very few examples of the contrary; for example, the Albanian State Aid Commission adopted only one negative decision between 2006 and $2016 .^{41}$ Decisions ordering the recovering of unlawful state aid are seldom passed. One of the rare examples of a decision ordering the recovery of granted state aid is the decision of the Montenegrin Commission for State Aid Control in the case of the Aluminium Plant Podgorica (KAP). ${ }^{42}$ Additionally, regarding the lenient approach of state aid authorities towards notified aid, one should understand that an important number of state aid grantors fail to notify the aid schemes. Since the SEE state aid authorities rarely initiate ex post control, a significant volume of granted aid is left out of the monitoring regime. Should one blame the institutional design of the SEE state aid authorities for their unsatisfactory enforcement record? It seems that the answer to this question should be negative, for four reasons, at least.

First, regardless of the model chosen - a state aid authority under the auspices of the government, broadly speaking, or a single competition and state aid authority accountable to parliament - the control of state aid in SEE countries cannot presently be performed in an entirely independent manner. The reasons for this can be found in the instability of democratic institutions in the region of South East Europe and the limited expertise within the state apparatus in the area of competition law and state aid. One would intuitively expect that a state aid authority accountable to parliament would be more immune to political influence. Still, one has to conclude that the establishment of a state aid authority, which is accountable to parliament instead to the government, does not necessarily prevent the influence of the executive power over the authority's activities. In SEE countries, the national parliaments have not yet fully developed as an independent branch of government. Instead, they are generally dominated by the executive branch and do not fulfil their role as the controller of the government (e.g. Stojiljković 2015). Therefore, both types of state aid authorities in SEE countries are still quite receptive to direct and indirect Governmental influence.

Second, the statistics does not support the hypothesis according to which a state aid authority accountable to the Parliament would be more efficient than the one established under the auspices of the Government. The enforcement record of the Macedonian state aid authority, for instance, is equally unsatisfactory as the results

\footnotetext{
${ }^{41}$ According to the authority's annual reports.

${ }^{42}$ Montenegro, Commission for State Aid Control, Kombinat Aluminijuma Podgorica (KAP), decision No 01-33/1, 1 June 2012.
} 
of state aid control in the countries that preferred the first type of institutional design of the monitoring authority. So far, the Macedonian state aid authority did not adopt a single decision prohibiting a state aid. ${ }^{43}$ The same "result" is achieved by the Serbian Commission for control of state aid—an authority which is accountable to the Government.

Third, we are of the view that the governments in the SEE countries do not sincerely support the activities of their state aid authorities. The majority of state aid authorities are understaffed and do not have the sufficient financial capacity to fulfil their mission in its entirety. Since state aid rules are a relatively novel element of the national legal regime, even the basic rules remain unknown to a significant number of state aid grantors. The monitoring authorities should therefore allocate sufficient resources to engage in advocacy activities. The latter are particularly important, given the fact that in all SEE countries large amounts of granted state aid are not being notified. This is especially the case with the aid granted by local authorities, which seem not to fully understand the system of state aid control. The central governments, on the other hand, generally do notify the state aid schemes and individual aid, but employ certain "avoidance strategies" in cases where it might be anticipated that a specific aid would not meet the criteria for approval; such aid is either intentionally not being notified (e.g. state aid provided for air transport in the FYR Macedonia) $)^{44}$ or gets authorised in a non-transparent procedure. For example, in the sensitive case of the takeover of the Serbian national air carrier Etihad Airways/Jat Airways (Air Serbia), the Serbian Commission for State Aid Control merely described the notified scheme and concluded that the latter conforms to the rules, without providing any in-depth reasoning behind such a conclusion (Popović and Caka 2017). ${ }^{45}$

Fourth, at the moment the achievement of efficient state aid control in SEE countries is not treated as a high priority requirement in the European Commission's pre-accession agenda. The support of the national governments in SEE countries for the activities of their state aid authorities would certainly be greater had the European Union exposed the candidate and potential candidate countries to more intensive political pressure in the area of state aid. The inefficiency of state aid authorities is in fact noted in the annual Progress Reports the European Commission adopts. For example, in the 2016 Montenegrin Report the Commission emphasised that the operational independence of the state aid authority has yet to be ensured and that the effectiveness of its control of state aid at all levels must be improved. However, it is also true that in the current, rather initial phase of the enlargement process, the efficiency of state aid control is not a requirement that the European Commission insists on being met. Given the EU's economic and political problems, it is evident that the SEE countries will not accede to the Union in the near future. Therefore, the

\footnotetext{
${ }^{43}$ According to the authority's annual reports.

${ }^{44}$ See The FYR Macedonia 2016 Progress Report, SWD (2016) 715 final, 40.

${ }^{45}$ Serbia, Commission for State Aid Control, Etihad Airways/Jat Airways (Air Serbia), decision No 142/2/2013-38, 21 February 2014.
} 
pre-accession process will last longer than in the case of the countries in Central and Eastern Europe. Judging from the experience of CEECs, the efficiency of state aid control will improve only when the country approaches the end of its European integration process (Atanasiu 2001; Birnstiel and Heinrich 2011; Cremona 2003; Evans 2004). The CEECs adopted state aid rules in the mature phase of the pre-accession process ${ }^{46}$ and their monitoring authorities started operating efficiently only when the EU accession date was (practically) determined. The efficient work of the national state aid authorities thus demonstrated that the countries in Central and Eastern Europe are prepared for the EU accession. Since the SEE countries established their state aid monitoring authorities at the beginning of their (ongoing) European integration process, and since the enlargement is no longer the European Union's priority, it seems highly likely that the state aid authorities in SEE countries will, for the time being, only continue with their pro forma activities, exposed to mild criticism of the European Commission.

Acknowledgment The author is grateful to Fjoralba Caka, Assistant Professor at the Faculty of Law, University of Tirana for assistance in researching and analysing Albanian and Kosovar legal sources.

\section{References}

Atanasiu I (2001) State aid in central and eastern Europe. World Compet 24:257-283

Begić Z, Delić Z (2013) Constituency of peoples in the constitutional system of Bosnia and Herzegovina: chasing fair solutions. Int J Const Law 11(2):447-465

Birnstiel A, Heinrich H (2011) State aid in the accession states. In: Szyszczak E (ed) Research handbook on European state aid law. Edward Elgar, Cheltenham, pp 44-63

Biukovic L (2008) The new face of CEFTA and its dispute resolution mechanisms. Rev Cent East Eur Law 33:253-294

Botta M (2013) State aid control in South-East Europe: The endless transition. Eur State Aid Law Q 12:83-94

Ceku OM (2015) Competition law in Kosovo: problems and challenges. Yearb Antitrust Regul Stud 8(12):101-127

Cremona M (2003) State aid control: substance and procedure in the Europe agreements and the stabilisation and association agreements. Eur Law J 9:265-287

Dangerfield M (2006) Subregional integration and EU enlargement: where next for CEFTA? J Common Mark Stud 44:305-324

Evans A (2004) Enlargement and state aid in CEECs. ClaSF Working Paper 4

Karova R (2010) Rationale behind the establishment of the energy community. EUI Working Paper Law 14

\footnotetext{
${ }^{46}$ Latvia and Hungary adopted national state aid rules in 1997, Estonia in 1998, Lithuania, Slovenia and Poland in 2000. These countries joined the European Union in 2004. Romania adopted its Law on State Aid Control in 2001 and joined the EU in 2007.
} 
Piszcz A (2011) Competition law in comparative perspective. Bialystok Law Books, Temida 2 Popović DV, Caka F (2017) State aid control in South-East Europe: waiting for a wake up call. Eur Bus Org Law Rev 18:333-349

Stojiljković Z (2015) Moć i nemoć parlamenta. In: Stojiljković Z, Lončar J, Spasojević D (eds) Parlament i demokratija. Fakultet političkih nauka Univerziteta u Beogradu, Belgrade, pp 7-20

Open Access This chapter is licensed under the terms of the Creative Commons Attribution 4.0 International License (http://creativecommons.org/licenses/by/4.0/), which permits use, sharing, adaptation, distribution and reproduction in any medium or format, as long as you give appropriate credit to the original author(s) and the source, provide a link to the Creative Commons license and indicate if changes were made.

The images or other third party material in this chapter are included in the chapter's Creative Commons license, unless indicated otherwise in a credit line to the material. If material is not included in the chapter's Creative Commons license and your intended use is not permitted by statutory regulation or exceeds the permitted use, you will need to obtain permission directly from the copyright holder. 